RECENZJE 

DOI : $10.14746 /$ ps.2017.1.37

\section{Jadwiga Kiwerska, Partnerstwo w przywództwie? Stany Zjednoczone i Niemcy (1989-2016). Perspektywa polska, Wydawnictwo Instytutu Zachodniego, Poznań 2017, ss. 398.}

Po zakończeniu II wojny światowej Stany Zjednoczone podjęly trudną decyzję, aby nie wycofywać się z Europy jak to mialo miejsce po 1918 r. Trwala obecność militarna, gospodarcza i polityczna USA na starym kontynencie (przynajmniej w zachodniej części) gwarantować miała jego bezpieczeństwo, gospodarczą odbudowę i zapobiec recydywie ustrojów totalitarnych. Nietrudno było zauważyć, że w polityce Waszyngtonu najważniejszą rolę odgrywaly Niemcy. To Stany Zjednoczone w warunkach zimnej wojny zadecydowaly o odbudowie państwa zachodnioniemieckiego i - co wówczas budzilo grozę wśród Europejczyków - zdecydowaly się na remilitaryzację RFN i przyjęcie tego państwa do NATO.

$Z$ biegiem czasu wzajemne relacje ewoluowaly. Niemcy zachodnie były cennym i odpowiedzialnym sojusznikiem, a ich wartość jako partnera gospodarczego systematycznie wzrastala, co wplywało na ich postrzeganie nad Potomakiem. Zjednoczenie Niemiec i upadek ZSRR przewartościowaly wzajemne relacje. Widać w nich bylo stabilność i trwalość (rządy H. Kohla), brak zaufania i napięcia (rządy G. Schrödera), odbudowę zaufania i powrót do zdystansowanej normalności (rządy A. Merkel 2005-2009), poprawność, ale chłód i pewna wstrzemięźliwość (rządy A. Merkel po 2009).

To tym właśnie zagadnieniom poświęcona jest najnowsza książka Jadwigi Kiwerskiej od wielu lat z powodzeniem specjalizującej się w problematyce amerykańskiej, a zwłaszcza w zakresie zaangażowania amerykańskiego w Europie. Książka stanowi syntetyczne ujęcie problemu trafnie zdefiniowanego jako ,partnerstwo w przywództwie”. Autorka zakłada pewną elementarną wiedzę u czytelnika o stosunkach niemiecko-amerykańskich. dlatego w jej ksiażce konkretnych faktów jest stosunkowo niewiele. Przeważają interesujące i poglębione analizy. Książka napisana jest lekkim naukowym językiem. Narracja jest wartka i wciagająca czytelnika. Autorka znakomicie panuje nad zebranym materiałem badawczym. Jej opinie i komentarze są sporządzane na solidnej podstawie źródlowej i wzbudzaja zaufanie czytelnika.

Pod względem merytorycznym, ale i technicznym Autorka podzieliła pracę na pięć rozdzialów, nie licząc Wstępu, Zakończenia, Bibliografii, Indeksu nazwisk i streszczenia w języku angielskim.

We Wstępie Autorka postawila wiele interesujących pytań badawczych, które oscyluja wokól problematyki definiowania przez USA polityki zwlaszcza wobec zjednoczonych Niemiec i zmieniającej się „ogólnej wartości” Stanów Zjednoczonych dla wzrastających w silę Niemiec, pełniących rolę niekwestionowanego lidera w Unii Europejskiej. J. Kiwerska stara się również wykazać, jaki wpływ relacje niemiecko-amerykańskie mają na politykę polską i jakimi zalożeniami Warszawa powinna kierować się $\mathrm{w}$ relacjach z dwoma najważniejszymi dla Polski partnerami.

Rozdzial pierwszy (Status lojalnego i oddanego sojusznika) nakreśla historyczne podstawy relacji amerykańsko-zachodnioniemieckich i wskazuje na ich najistotniejsze okresy. W tym rozdziale wspomnialbym nieco więcej o niewdzięcznej roli Adenauera na rzecz 
budowy sojuszu z Amerykanami i światem zachodnim. Od niedawna się otwarcie pisze o lukrowanej wcześniej przez historiografię powojennej niemieckiej rzeczywistości, gdzie milczano o stosunku pokonanych Niemców do amerykańskich okupantów, którzy zwłaszcza w latach 1943-1945 systematycznie równali niemieckie miasta z ziemią. Życzliwości tam żadnej nie było i wielkiej trzeba było zręczności, uporu i daru przekonywania u Adenauera, by przekonać rodaków co do celowości sojuszu z wczorajszym wrogiem.

W rozdziale drugim (W pozimnowojennych uwarunkowaniach) w dużym stopniu uwaga Autorki skoncentrowana zostala na problemie zjednoczenia Niemiec i wynikajacych z tego wydarzenia konsekwencjach. Autorka opisuje poszukiwanie przez Niemcy swojej nowej roli w Europie i świecie oraz przemiany, które zaszly w polityce amerykańskiej po reunifikacji dwóch państw niemieckich i rozpadzie komunizmu. Ciekawy i z werwą napisany rozdzial trzeci (Wzrost odpowiedzialności Niemiec) analizuje relacje niemiecko-amerykańskie i wewnętrzną scenę polityczną Niemiec w okresie wojny w Zatoce Perskiej, konfliktu w Bośni-Hercegowinie i Kosowie. Podejmuje także temat stanowiska obu państw wobec wschodniego rozszerzenia NATO.

Jeden z najważniejszych rozdziałów pracy, czwarty (W cieniu wojny z terroryzmem), analizuje okres najtrudniejszy dla partnerstwa niemiecko-amerykańskiego, kiedy doszlo do licznych kontrowersji we wzajemnych relacjach wynikających z unilateralizmu polityki G. W. Busha w okresie walki z terroryzmem islamskim i w czasie interwencji w Afganistanie i Iraku. Ostatni, piaty rozdzial (Obama i Merkel - partnerstwo) nie ma tak dynamicznego charakteru jak poprzedni, ale jego lektura również sprawia satysfakcję czytelnikowi. Autorka tutaj przybliża czytelnikowi prezydenturę Baracka Obamy i nakreśla jego dość dwuznaczny stosunek do Niemiec i szerzej do Europy. Punktami ciężkości dla wzajemnych odniesień była arabska wiosna, wojna we wschodniej Ukrainie, konflikt w Syrii i kryzys zwiazzany z uchodźcami.

Przechodząc do generalnych uwag i spostrzeżeń można powiedzieć, że otrzymaliśmy wartościową książkę, która znacznie wzbogaca polski dorobek w dziedzinie stosunków międzynarodowych ze wskazaniem na badania niemcoznawcze i amerykanistyczne. Jest to poglębione studium stopniowo zmieniających się relacji niemiecko-amerykańskich od swoistego patronatu USA nad młodym państwem zachodnioniemieckim po relacje prawie partnerskie we wspólczesności, gdzie Niemcy zachowują się jak pełnoprawny uczestnik wielkiej polityki międzynarodowej. Książka z pewnością znajdzie uznanie nie tylko specjalistów, lecz stanie się również dobrą lekturą dla dziennikarzy, studentów i nauczycieli.

Bogdan KOSZEL 